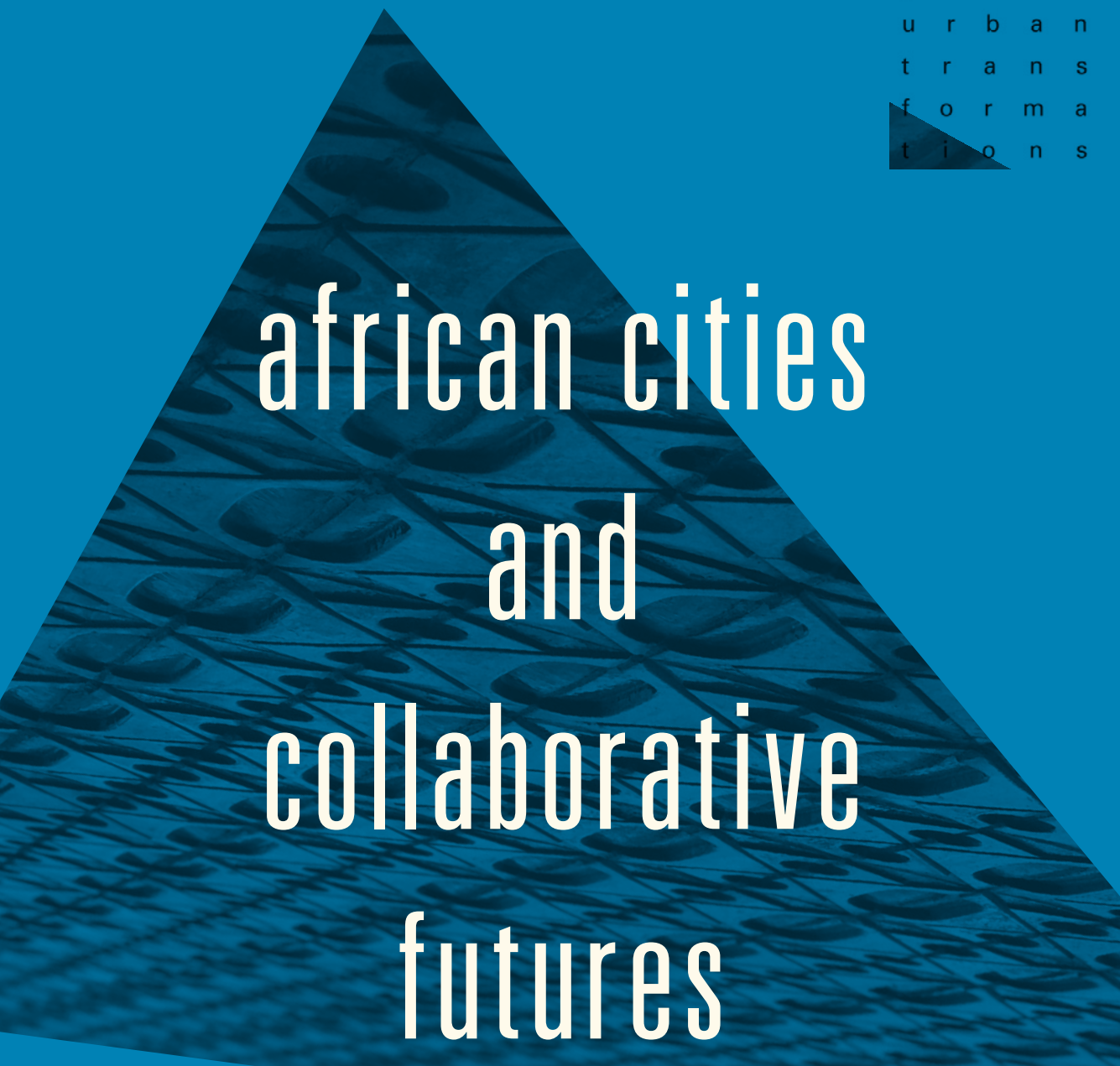

urban platforms and metropolitan logistics

edited by michael keith and

andreza aruska de souza santos 


\section{African cities and collaborative futures}

\section{MANCHESTER 1824}

Manchester University Press 


$$
\begin{array}{cccccc}
g & \text { l } & \text { o } & b & a & \text { l } \\
\text { u } & r & b & a & n \\
t & r & a & n & s \\
f & o & r & m & a \\
t & i & o & n & s
\end{array}
$$

\author{
Previously published
}

Urban transformations and public health in the emergent city Edited by Michael Keith AND Andreza Aruska de Souza Santos 


\title{
African cities and collaborative futures
}

\author{
Urban platforms and \\ metropolitan logistics
}

\author{
Edited by Michael Keith and \\ Andreza Aruska de Souza Santos
}

Manchester University Press 
While copyright in the volume as a whole is vested in Manchester University Press, copyright in individual chapters belongs to their respective authors.

This electronic version has been made freely available under a Creative Commons (CC-BY-NC-ND) licence, which permits non-commercial use, distribution and reproduction provided the editors, chapter authors and Manchester University Press are fully cited and no modifications or adaptations are made. Details of the licence can be viewed at https://creativecommons.org/licenses/by-nc-nd/4.0/

Published by Manchester University Press

Altrincham Street, Manchester M1 7JA

www.manchesteruniversitypress.co.uk

British Library Cataloguing-in-Publication Data

A catalogue record for this book is available from the British Library

ISBN 9781526155368 hardback

ISBN 9781526155351 open access

First published 2021

The publisher has no responsibility for the persistence or accuracy of URLs for any external or third-party internet websites referred to in this book, and does not guarantee that any content on such websites is, or will remain, accurate or appropriate.

Cover design: Daniel Benneworth-Gray

Photo: Claire Forbes on Unsplash

Typeset

by New Best-set Typesetters Ltd 